\title{
PERLUASAN DAN PEMERATAAN AKSES PENDIDIKAN DI KABUPATEN SORONG
}

\author{
The Expansion And The Equity Of Educational Access \\ in Sorong
}

Badruzzaman

Balai Penelitian dan Pengembangan Agama Makassar

Jl. A.P. Pettarani No. 72 Makassar

Email: bz69badruzzaman@rocketmail.com

Naskah diterima tanggal 3 Desember 2012. Naskah direvisi tanggal 26 Desember 2012. Naskah disetujui tanggal 26 Januari 2013

\begin{abstract}
Abstrak
Ditjen Pendidikan Islam mengarahkan kebijakan perluasan dan pemerataan Akses Pendidikan 20042009 pada upaya perluasan daya tampung satuan Pendidikan Islam dengan mengacu kepada skala prioritas nasional dengan memberikan kesempatan yang sama bagi seluruh peserta didik dari berbagai golongan masyarakat yang berbeda. Tujuan penelitian untuk mengatahui tingkat implementasi kebijakan Perluasan dan Pemerataan Akses Pendidikan Agama Islam di Kabupaten Sorong dan peningkatan daya tampung madarasah setelah impelementasi kebijakan tersebut. Hasil penelitian ini menemukan bahwa satuan pendidikan agama Islam telah tersentuh program perluasan dan pemerataan akses pendidikan agama Islam, namun tingkat ketersentuhan itu tampak belum menyeluruh, demikian halnya pada kebijakan peningkatan kesejahteraan guru dan bantuan beasiswa bagi siswa. Penentuan satuan pendidikan yang menjadi sasaran program perluasan dan pemerataan akses pendidikan agama yang mempertimbangkan secara proporsional antara satuan pendidikan umum dan satuan pendidikan agama.
\end{abstract}

Kata kunci: perluasan, pemerataan, akses pendidikan

\begin{abstract}
The Directorate General of Islamic Education directed the policy of expansion and equity of educational access of 2004-2009 in attempt to expand Islamic Education unit capacity referring to the national priority scale by providing equal opportunity to all learners from different level of society. The research aimed at identifying the policy implementation level of expansion and equity of Islamic educational access in Sorong regency and the capacity improvement of Islamic schools (Madarasah) after implementing the policy. The findings show that Islamic education units have been affected with the expansion and equity of Islamic education access, however, the level of result looked incomplete particularly on the teachers' welfare policy and scholarship for students. The determination of educational units which become the targeted program of expansion and equity of Islamic educational access was proportionally considered between public education units and Islamic education units.
\end{abstract}

Keywords: expansion, equity, educational access

\section{PENDAHULUAN}

$\mathrm{P}$ emerataan pendidikan menjadi salah satu cita-cita bangsa. Berbagai undang-undang disahkan dan dana dialokasikan untuk cita- cita itu. Undang-Undang Dasar Republik Indonesia 1945 menyatakan, bahwa pemerintah berkewajiban untuk memenuhi hak setiap warga negara dalam memperoleh layanan pendidikan guna meningkatkan kualitas hidup bangsa Indonesia. 
Sejalan dengan itu, Undang-Undang Republik Indonesia Nomor 20 Tahun 2003 tentang Sistem Pendidikan Nasional (Sisdiknas) pasal 5 ayat (1) menyatakan bahwa "Setiap warga negara mempunyai hak yang sama untuk memperoleh pendidikan yang bermutu", dan pasal 11 ayat (1) menyatakan, bahwa Pemerintah dan Pemerintah Daerah wajib memberikan layanan dan kemudahan serta menjamin terselenggaranya pendidikan yang bermutu bagi setiap warga negara tanpa diskriminasi.

Sejak tahun 1984, pemerintah Indonesia secara formal telah mengupayakan pemerataan pendidikan Sekolah Dasar, dilanjutkan dengan wajib belajar pendidikan sembilan tahun mulai tahun 1994 (Saud, 2011: 122). Kemudian secara operasional pemerataan kesempatan memperoleh pendidikan dirumuskan dalam kebijakan pembangunan di bidang pendidikan pada tahun 2007, yang mencakup: pemerataan dan perluasan akses pendidikan, peningkatan mutu, relevansi dan daya saing, dan peningkatan tata kelola, akuntabilitas dan pencitraan (Dirjen Pendais, 2008: 25).

Regulasi Sisdiknas yang disebut terdahulu menegaskan bahwa strategi pertama dalam melaksanakan pembaruan sistem pendidikan nasional adalah "pelaksanaan pendidikan agama dan akhlak mulia". Oleh karenanya pendidikan keagamaan jelas merupakan salah satu pilar utama untuk mewujudkan tujuan pendidikan nasional yang dirumuskan regulasi tersebut. Hal ini mengisyaratkan arti pentingnya pendidikan agama dan keagamaan dalam sistem pendidikan.

Berdasarkan tiga kebijakan pembangunan pendidikan diatas maka Kementerian Agama RI dalam hal ini Ditjen Pendidikan Islam 2004-2009 mengarahkan kebijakan Pembangunan Pendidikan Islam dalam Rencana Strategis (Renstra) Ditjen Pendidikan Islam 2004-2009, sebagaimana dinyatakan dalam Rencana Pembangunan Jangka Menengah (RPJM) 2004-2009 bidang pendidikan kepada tiga kebijakan. Tiga kebijakan tersebut terdiri dari: (1) perluasan dan pemerataan akses, diitujukan kepada upaya perluasan daya tampung satuan Pendidikan Islam dengan mengacu kepada skala prioritas nasional dengan memberikan kesempatan yang sama bagi seluruh peserta didik dari berbagai golongan masyarakat yang berbeda baik secara sosial ekonomi, gender, lokasi tempat tinggal dan tingkat kemampuan intelektual serta kondisi fisik. (2). Peningkatan mutu, relevansi, dan daya Saing; diarahkan pada peningkatan mutu Pendidikan Islam sehingga dapat memenuhi Standar Nasional Pendidikan (SNP), dan (3). Peningkatan tata kelola dan pencitraan yang diarahkan pada pembenahan perencanaan jangka menengah dengan menetapkan kebijakan strategis serta program-program yang didasarkan berdasarkan skala prioritas (Dirjen Pendais, 2004: 94).

Keberhasilan pembangunan pendidikan Islam mengacu tiga tema pokok kebijakan pembangunan pendidikan diantaranya, yaitu: perluasan dan pemerataan akses (Dirjen Pendais, 2004: 94). Pengertian perluasan dan pemerataan akses pendidikan, ditujukan kepada upaya perluasan daya tampung satuan pendidikan Islam, dilaksanakan dengan mengacu kepada skala prioritas nasional dengan memberikan kesempatan yang sama bagi seluruh peserta didik dari berbagai golongan masyarakat yang berbeda lokasi tempat tinggal. Kebijakan pemerataan dan perluasan akses ditujukan untuk memberikan kesempatan yang seluas-luasnya bagi penduduk untuk dapat belajar sepanjang hayat. Pada tahun 2008, kebijakan perluasan dan pemerataan akses pendidikan Islam akan diupayakan secara sistematis untuk peningkatan kapasitas daya tampung dengan program perluasan dan pemerataan pembangunan pendidikan agama Islam pada MI, MTs, dan MA: (a) meningkatkan sarana dan prasarana Pendidikan Agama termasuk sarana olah raga termasuk rehailitasi bangunan, pengadaan unit sekolah baru, penambahan ruang kelas baru, sarana ibadah, perpustakaan, laboratorium, sarana olah raga. (b) memberikan subsidi pendidikan bagi sekolah negeri dan swasta agar mampu menyelenggarakan pendidikan yang berkualitas dan memberikan pelayanan pendidikan agama Islam yang dapat dijangkau masyarakat luas dalam hal ini masyarakat di daerah tertinggal. (c) peningkatan kesejahteraan guru dengan memberikan tunjangan kepada guru tertinggal (Dirjen Pendais, 2004: 95).

Masyarakat di daerah tertinggal dapat didefinisikan sebagai masyarakat kabupaten yang masyarakatnya serta wilayahnya relatif mengalami perkembangan yang sangat lambat dibandingkan dengan masyarakat lain dalam skala nasional (Kumiati, 2012: 92). Namun Kementerian Pembangunan Daerah Tertinggal mendefinsikan daerah tertinggal adalah adalah daerah kabupaten yang relatif kurang berkembang dibandingkan daerah lain dalam skala nasional, dan berpenduduk 
yang relatif tertinggal (Departemen Pembangunan Daerah Tertinggal, 2005: 5).

Menurut Anna Kurniati dan Ferry Efendi ada enam kriteria dasar masyarakat tertinggal yang digunakan dalam penyusunan potensi desa pada tahun 2003 dan Survei Sosial Ekonomi Nasional (Susenas) 2003, antara lain perekonomian masyarakat, sumber daya manusia, prasana (infrastruktur), Kemampuan keuangan lokal (celah fiskal), aksesibilitas dan karakeristik daerah, serta berdasarkan kabupaten yang berada di daaerah perbatasan antarnegara dan gugusan pulau-pulau kecil, daerah rawan bencana, dan daerah rawan koflik (Kumiati, 2012: 93). Kriteria tersebut tampaknya disesuaikan dari rumusan kriteria daerah tertinggal telah dibuat oleh Kementerian Pembangunan Daerah Tertinggal pada tahun 2005 (Departemen Pembangunan Daerah Tertinggal, 2005: 5).

Hal ini sesuai dengan Undang-Undang Nomor 32 Tahun 2004 tentang pemerintah daerah yakni kewenangan pelaksanaan pembangunan secara penuh diberikan kepada pemerintahan kabupaten. Oleh sebab itu, daerah tertinggal dalam penelitian ini mengacu kepada daerah tertinggal menurut kepala Kantor Departmen Agama di Daerah penelitian karena mereka yang lebih mengetahui tentang ketertinggalan di wilayahnya di bidang pendidikan agama dan keagamaan.

Data Kementerian Perencanaan Pembangunan Nasional dan Perencanaan Pembangunan Nasional (Bappenas), dari Rangkuman Rencana Pembangunan Jangka Menengah Nasional (RPJMN) Tahun 2010-2014 prioritas bidang kawasan daerah tertinggal, menunjukkan bahwa terdapat 183 Kabupaten tertinggal di Indonesia 8 Kabupaten di Papua Barat diantaranya Kabupaten Sorong.

Berdasarkan uraian sebelumnya, maka masalah penelitian adalah: Bagaimana tingkat implementasi kebijakan nasional tentang perluasan dan pemerataan akses pendidikan pada madrasah di Kabupaten Sorong, serta peningkatan daya tampung madarasah setelah implementasi kebijakan tersebut?

Hasil penelitian diharapkan dapat memberikan kontribusi secara akademik terhadap pengembagan ilmu pemerintahan/pembangunan khususnya memperkaya fenomena yang berkaitan dengan teori implementasi pembangunan. Demikian halnya dengan kontribusi praktis terhadap pembangunan pendidikan, diharapkan dapat menjadi bahan kebijakan dalam rangka meningkatkan pembangunan pendidikan agama dan keagamaan khususnya di daerah yang tergolong tertinggal.

\section{Tinjauan Pustaka}

Kunci dari pembangunan adalah kemakmuran bersama. Pemerataan hasil pembangunan dan pertumbuhan kesejahteraan yang tinggi merupakan tujuan pembangunan yang ingin dicapai. Tingkat pertumbuhan yang tinggi tanpa disertai pemerataan pembangunan hanyalah menciptakan kesejanteraan yang lemah dan eksploitasi sumber daya manusia. Meskipun pembangunan harus berkeadilan, tetapi disadari bahwa pertumbuhan tetap penting. Upaya memadukan konsep pertumbuhan dan pemerataan merupakan tantangan yang jawabannya tidak hentihentinya dicari dalam studi pembangunan. Bank Dunia telah mensponsori studi pada tahun 1974 dan mengembangkansebuahmodelyangdinamaidengan Redistribution with Growth (RWG). Ide dasarnya adalah pemerintah harus mempengaruhi pola pembangunan sedemikian rupa sehingga produsen (rakyat/masyarakat) yang berpenghasilan rendah (tingkat kesejahteraan rendah) akan mendapat kesempatan meningkatkan pendapatannya/ kesejahteraannya dan secara simultan menerima sumber ekonomi (bantuan pembangunan) yang diperlukan (Wrihatnolo, 2007: 67-68). Formulasi ini mengajukan makna baru pembangunan yang kurang menekankan pada pendekatan pertumbuhan ekonomi. Pembangunan dipandang sebagai kemajuan menuju kepada tercapainya tujuan seperti penghapusan kemiskinan, ketersediaan tenaga kerja, pengurangan ketidaksertaan serta menjamin terpenuhinya hak asasi manusia (Winarno, 2008: 12-13). Paradigma pembangunan ini memberikan implikasi lebih lanjut dengan terlihatnya sloganslogan seperti "redistribusi dengan pertumbuhan" (redistribution with growth); kalau dalam kebijakan dikenal dengan pendekatan "kebutuhan dasar" (the basic need approach); kalau dalam paket-paket perencanaan dikenal misalnya "pembangunan desa terpadu" (integrated rural development). Pola yang sama juga dilakukan dalam kebijakan pembanguan pendidikan, termasuk pembangunan pendidikan agama dan keagamaan dengan jargon "Perluasan dan Pemerataan Akses Pendidikan"; pendistibusian program pembangunan agar semua rakyat dapat mengakses pendidikan dalam rangka menumbuhkan kesejahteraan.

Perluasan dan pemerataan pendidikan juga mencakup dua aspek penting yaitu equality dan 
equity. Equality atau persamaan mengandung arti persamaan kesempatan untuk memperoleh pendidikan, sedangkan equity bermakna keadilan dalam memperoleh kesempatan pendidikan yang sama di antara berbagai kelompok dalam masyarakat. Akses terhadap pendidikan agama yang merata berarti semua penduduk usia sekolah telah memperoleh kesempatan pendidikan agama; sementara itu akses terhadap pendidikan telah adil jika antar kelompok bisa menikmati pendidikan agama secara sama (Prijono, 1996: 97).

\section{METODE PENELITIAN}

Penelitian kualitatif ini menggunakan pendekatan empiris dan evaluatif. Pendekatan empiris digunakan untuk menganalisis sebab dan akibat dari kebijakan perluasan dan pemerataan pendidikan agama, dan pendekatan evaluatif digunakan untuk menganalisis penentuan bobot atau nilai dari beberapa kebijakan yang dimaksud. Sementara sasaran penelitian adalah MI, MTs dan MA yang tedapat di Kabupaten Sorong. Data diperoleh dari instansi terkait, Kementerian Agama Kabupaten Sorong, kepala dan guru madrasah, dan dokumen kementerian dan madrasah, dengan menggunakan matriks data berdasarkan variabel dan sumber data, serta daftar item wawancara dan pengamatan. Data dianalisis dengan tiga tahap, yaitu reduksi data, penyajian data, dan penarikan kesimpulan.

\section{PEMBAHASAN}

\section{Perluasan dan Pemerataan Akses Pendidikan Agama}

Salah satu pilar pendidikan nasional adalah perluasan dan pemerataan akses pendidikan. Perluasan dan pemerataan akses pendidikan yang ditujukan dalam upaya perluasan daya tampung satuan pendidikan dengan mengacu pada skala prioritas nasional yang memberikan kesempatan yang sama bagi seluruh peserta didik dari berbagai golongan masyarakat yang beraneka ragam baik secara sosial, ekonomi, gender, geografis, maupun tingkat kemampuan intelektual, dan kondisi fisik. Perluasan dan pemerataan akses memberikan kesempatan yang seluas-luasnya bagi penduduk Indonesia untuk dapat belajar sepanjang hayat dalam rangka peningkatan daya saing bangsa di era globalisasi.

\section{Peningkatan Fasilitas Fisik Pendukung Proses \\ Pembelajaran}

Salah satu bentuk kegiatan dalam upaya mengimplementasikan kebijakan nasional di bidang pendidikan pada aspek perluasan dan pemerataan akses pendidikan adalah peningkatan fasilitas fisik pendukung proses pembelajaran. Ada dua bentuk kegiatan yang mencakup peningkatan fasilitas fisik pendukung proses pembelajaran yaitu: (a) rehabilitasi gedung sekolah/ruang kelas, pengadaan/ rehabilitasi sumber dan sanitasi air bersih serta kamar mandi dan wc, pengadaan/perbaikan meubiler ruang kelas, lemari perpustakaan dan pembangunan/rehabilitasi rumah dinas penjaga/guru/kepala sekolah; (b) mengadakan sarana pendidikan dan sarana perpustakaan mencakup: alat peraga pendidikan, buku pengayaan, buku referensi, dan sarana multimedia (Departemen Diknas, 2007: 6).

Rehabilitasi Gedung Satuan Pendidikan Agama

Program rehabilitasi bangunan satuan pendidikan agama di Kabupaten Sorong, tampak terimplementasi. Hal ini dapat dilihat pada alokasi program rehabilitasi itu tersasarkan ke satuansatuan pendidikan agama, baik negeri maupun swasta, setidaknya lima tahun terakhir (tahun 20052009).

Pada tahun 2006 ada sejumlah dua madrasah yang telah menerima dana rehabilitasi sarana fisik, yaitu Madrasah Ibtidayah Swasta (MIS) Istiqamah dan MIS Al Muhajirin. Kedua MIS tersebut masingmasing telah mendapatkan sejumlah Rp. 54.000.000 dan digunakan untuk merehabilitasi ruang sejumlah masing-masing 8 kelas. MIS Al Maarif I dan MIS Al Ma’arif II juga mendapatkan dana untuk membangun kelas baru sebanyak masing-masing 4 lokal.

Program tersebut tersasarkan pula untuk merehabilitasi fisik gedung sekolah/ruang kelas juga disasarkan untuk membuat atau merehabilitasi sarana olahraga. Peruntukan ini, MTsN Kabupeten Sorong, pada tahun yang sama telah mendapat anggaran dan digunakan membangun sarana olahraga, yaitu lapangan volly beserta alat olahraga.

Pada tingkat madrasah aliyah, pembiayaan dalam rangka peningkatan kualitas pendidikan bersumber dari Dana Operasional Peningkatan Mutu Pendidikan (BOMM). Program bantuan yang diadakan oleh Kementrian Agama melalui 
Bagian Proyek Peningkatan Mutu Pendidikan Dasar dan Menengah diimplentasikan dalam bentuk Blok Grand, untuk diberikan kepada madrasah tsanawiyah dan madrasah aliyah, baik negeri maupun swasta di seluruh Indonesia. Bantuan tersebut untuk mendorong peningkatan mutu pendidikan berdasarkan prinsip-prinsip Manajemen Berbasis Sekolah (MBS). Oleh karena itu, programnya difokuskan pada mutu, pengelolaan, atau manajemen yang transparan, perencanaan dan pengambilan keputusan yang melibatkan semua warga madrasah, pemberdayaan masyarakat, serta peningkatan mutu secara berkelanjutan. Kabupaten Sorong mendapatkan dana BOMM pada 2006 sejumlah 75.000.000, dan diperuntukkan kepada MA Hidayatullah. Penentuan MA Hidayatullah sebagai penerima bantuan BOMM dilakukan dengan mempertimbangkan kriteria dan persyaratan sesuai dengan yang ditetapkan oleh program tersebut, serta dilakukan seleksi pada tingkat kabupaten (Bidang Mapenda Tingkat Kabupaten/Kota), tingkat Provinsi (Kanwil Kemerterian Agama Bidang Mapenda) dan tingkat pusat (Ditmapenda Islam/Proyek).

Pada tahun 2007, program rehabilitasi bangunan satuan pendidikan agama tampaknya telah berjalan dengan baik, terutama pada upaya peningkatan mutu pendidikan termasuk pendidikan agama dan keagamaan di Kabupaten Sorong. Peningkatan mutu pendidikan agama di Kabupaten Sorong telah diimplementasikan dengan memberikan bantuan pembangunan dan/ atau rehabilitasi laboratorium. MTsN Mariyai, pada tahun 2007 telah mendapat bantuan dalam bentuk dana blok grand sejumlah Rp. 250.000.000,dan dipergunakan untuk membangun gedung laboratorium IPA. Sedangkan MA Hidayatullah mendapatkan dana BOMM yang kedua kalinya, sejumlah Rp. 75.000.000,-.

Pada tahun 2008, lembaga pendidikan agama dan keagamaan di Kabupaten Sorong pun mendapat bantuan, diantaranya: MTsN Mariyai, mendapat bantuan yang kedua kalinya sejumlah $\mathrm{Rp}$ 250.000.000, dan dimanfaatkan untuk membangun gedung multimedia interaktif beserta perangkat alat multimedia. Madrasah swasta pun mendapatkan bantuan yang sama, yaitu MIS Al Ma'arif III dalam bentuk pembangunan kelas baru sejumlah 3 lokal.

Selain itu, Kabupaten Sorong mendapat pula bantuan pembinaan OSIS dari Departemen Agama dan disalurkan ke madrasah yang memenuhi syarat, yaitu MAS Hidayatullah. Untuk ketiga kalinya MAS tersebut mendapatkan bantuan operasional peningkatan mutu madrasah yang kali ini sebanyak 10 juta. Selain dana bantuan pembinaan OSIS, madrasah tersebut juga mendapatkan dana bantuan penyelenggaraan Porseni siswa sebanyak Rp. $5.000 .000,-$.

Pada tahun 2009, program rehabilitasi dan membangun beberapa sarana fisik pun tampak. Lembaga pendidikan agama yang mendapatkan dana bantuan rehabilitasi pada tahun 2009 adalah MTsN Mariyai. Jumlah dana yang diperoleh adalah Rp. 24.000.000, dan telah digunakan untuk merehabilitasi ruang guru dan memperbaiki halaman sekolah.

Selain itu, madrasah aliyah juga mendapatkan subsidi peningkatan kualitas sarana pembelajaran. Subsidi tersebut disasarkan untuk merehabilitasi dan/atau membangun ruang kelas baru. Salah satu MA yang mendapatkan subsidi berupa pembangunan kelas adalah MAS Al Ma'arif. MAS tersebut mendapat bantuan pembangunan kelas pada tahun 2005. MAS yang lain yang turut mendapatkan subsidi pembangunan kelas baru adalah MAS Muhammadiyah, pada tahun 2008 (Sumber data: Kantor Departemen Agama RI Kabupaten Sorong).

\section{Bantuan Pengadaan Sarana/Alat Pembelajaran}

Program peningkatan fasilitas fisik pendukung proses pembelajaran tampak pula pada kegiatan pengadaan sarana/alat pembelajaran. Bantuan sarana/alat pembelajaran itu berupa pengadaan meubiler perpustakaan; pengadaan sarana pendidikan dan sarana perpustakaan mencakup: pengadaan alat peraga dan multimedia interaktif, buku pengayaan, buku referensi, dan alat teknologi informasi dan komunikasi serta alat elektronika.

Implementasi pengadaan sarana pendidikan dan sarana perpustakaan tersebut telah dilakukan, baik pada lembaga-lembaga pendidikan keagamaan, seperti madrasah. Lembaga pendidikan agama yang secara rutin mendapat anggaran pengadaan sarana pendidikan adalah MIN Malewale melalui DIPA. Madasarah ibtidaiyah yang satu-satunya berstatus negeri itu mendapatkan bantuan pengadaan sarana pendidikan berupa 3 buah printer dan 7 buah alat musik daerah pada tahun 2005. Tiga buah printer itu berharga Rp. 1.950 .000 dan 7 buah alat musik 
daerah berharga Rp. 1.050.000,-. Tahun 2006 madrasah tersebut pun telah mengadakan 8 buah meja kerja kaju yang senilai Rp. 3.600.000,- dan 4 buah komputer yang senilai Rp. 44.000.000,Dan pada tahun 2007 madrasah itu juga telah mendapatkan beberapa sarana pendidikan, antara lain sejumlah kursi besi, televisi, loadspeaker, audio system, multimedia, printer, laptop, kendaraan roda dua dan lain sebagainya.

\section{Peningkatan Kesejahteraan Guru}

Selain peningkatan kualitas sarana fisik pendukung proses pembelajaran, implementasi kebijakan nasional bidang pendidikan dalam hal perluasan dan pemerataan akses juga berupa peningkatan kesejahteraan guru.

Ada sejumlah kebijakan nasional dalam upaya meningkatkan kesejahteraan guru, antara lain pemberian tunjangan guru baik PNS maupun honorer, dan pemberian tunjangan daerah khusus bagi guru-guru yang ditempatkan daerah terpencil. Menurut data yang diperoleh dari Direktorat Jenderal Pendidikan Islam Departemen Agama RI, bahwa jumlah guru baik PNS maupun non PNS di Kabupaten Sorong adalah 171 orang, 64,3\% di antaranya masih berstatus non PNS. Sejumlah guru tersebut yang diprogramkan untuk mendapatkan tunjangan non PNS dan tunjangan daerah khusus. Untuk lebih jelasnya dapat dilihat pada Tabel 1berikut:

Tabel 1

Jumlah Guru PNS dan Non PNS

Berdasarkan Tingkatan dan Jenis Satuan Pendidikan Agama

\begin{tabular}{|c|c|c|c|c|}
\hline Madr & & Status $\mathrm{Ke}$ & uruan & \\
\hline $\mathrm{PN}$ & & Non PNS & & Jumlah \\
\hline Ihtidaivah & 1 Negeri & 16 & 2 & 18 \\
\hline 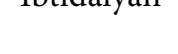 & 8 wasta & 19 & 26 & 45 \\
\hline Jum & & 35 & 28 & 28 \\
\hline Tcanamixah & 1 Negeri & 10 & - & 10 \\
\hline isanawıyan & 8 wasta & 7 & 54 & 61 \\
\hline Jum & & 17 & 54 & 54 \\
\hline Alingh & - & - & - & \\
\hline Allyan & 8 wasta & 9 & 28 & 37 \\
\hline Jum & & 9 & 28 & 37 \\
\hline Tot & & 61 & 110 & 171 \\
\hline
\end{tabular}

54 | Jurnal “Al-Qalam” Volume 19 Nomor 1 Juni 2013
Tunjangan guru non PNS mendapatkan sejumlah Rp. 3.000.000,- perorang per tahun. Selain itu guru juga mendapat tunjangan dareah khusus, yaitu sejumlah Rp. 16.500.000, perorang pertahun (Wawancara: Kepala Seksi Mapenda Kantor Departemen Agama RI Kabupaten Sorong).

\section{Bantuan Beasiswa Bagi Siswa}

Program lain yang ditujukan untuk mengimplementasikan kebijakan nasional bidang pendidikan 'perluasan dan pemerataan akses pendidikan agama' adalah pemberian beasiswa kepada siswa miskin. Program beasiswa tersebut disalurkan oleh Departemen Agama RI.

Program beasiswa bagi siswa miskin yang disalurkan oleh Departemen Agama RI tampaknya bervariasi jumlahnya di setiap tingkatan satuan pendidikan. Jumlah beasiswa miskin bagi siswa MI sebesar Rp. 360.000,- pertahun persiswa, MTs sebesar Rp. 720.000,- per tahun persiswa dan MA sebesar Rp. 760.000,- pertahun persiswa. Proses penyaluran dana beasiswa tersebut langsung dari Kantor Departemen Agama Pusat ke rekening MI, MTs dan MA yang dituju. Selanjutnya, pihak madrasah yang mencairkan dan memberikan dana beasiswa tersebut langsung kepada siswa yang bersangkutan.

Satuan pendidikan agama di Kabupaten Sorong pun telah mendapatkan bantuan dana beasiswa miskin ini. Hampir semua madrasah baik tingkatan MI, MTs maupun MA mendapatkan bantuan dana beasiswa ini. Salah satu madrasah yang telah mendapatkan bantuan adalah MIN Malewale. Pada tahun 2008 madarasah ini mendapatkan bantuan beasiswa miskin sebanyak 16 orang, pada tahun 2009 sebanyak 19 orang, dan tahun 2019 sebanyak 17 orang. Demikian halnya pada madrasah MTsN Mariyai, pada tahun 2008, madrasah ini mendapatkan bantuan dana beasiswa miskin dan telah disalurkan kepada sejumlah 16 orang siswa, pada tahun 2009 diberikan kepada sejumlah 19 orang, dan pada tahun 2010 diperuntukkan kepada sejumlah 17 orang. (Sumber data: MIN Malewale Kab. Sorong).

Selain itu, siswa-siswa madrasah yang menyelengarakan wajib belajar 9 tahun (MI dan MTs) tidak dipungut lagi biaya sekolah. Hal ini disebabkan oleh setiap satuan pendidikan agama dan keagamaan itu telah mendapatkan Bantuan Operasional Sekolah (BOS). Bantuan BOS yang disalurkan oleh Departemen Agama tahun 2009, 
juga tampak bervariasi berdasarkan lokasi dan tingkatan madrasah itu. Untuk MI atau Salafiyah Ula jumlah sebesar Rp. 397.000,- persiswa madrasah yang berlokasi di kabupaten, dan madrasah yang berlokasi di kota mendapatkan dana BOS sejumlah Rp. 400.000,- per siswa. Demikian halnya pada tingkatan MTs atau Salafiyah Wustha mendapatkan dana BOS sebesar Rp. 570.000,- bagi madrasah yang berlokasi di kabupaten dan sejumlah Rp. 570.000 bagi madrasah yang berlokasi di kota (Sumber data: Kantor Departemen Agama Kab. Sorong). Lebih jelasnya dapat dilihat pada tabel 2 berikut.

Tabel 2

Variasi Jumlah Dana Beasiswa dan BOS pada setiap Tingkatan Pendidikan

\begin{tabular}{cccc}
\hline Jenis Bantuan & Tingkatan Madrasah & Kota & Kabupaten \\
\hline \multirow{2}{*}{ BOS } & MI/Salafiyah Ula & Rp. Rp. 397.000,- & Rp. 400.000,- \\
& MTs/Salafiyah Wustha & Rp. 570.000,- & Rp. 570.000,- \\
& MI/Salafiyah Ula & Rp. 360.000,- \\
\multirow{2}{*}{ Beasiswa Miskin } & MTs/Salafiyah Wustha & Rp. 720.000,- \\
& MA/ Salafiyah Ulya & Rp. 760.000,- \\
\hline
\end{tabular}

\section{Peningkatan DayaTampung Madrasah Peningkatan Jumlah Siswa Madrasah}

Salah satu indikator perluasaan dan peningkatan akses pendidikan adalah tingkat daya tampung satuan pendidikan. Hal ini dapat diamati lewat peningkatan jumlah siswa baru setiap tahunnya, dengan memperlihatkan tingkat akomodasi satuan pendidikan terhadap siswa dengan ragam latar belakang sosial ekonomi, antara lain, agama, suku, ras dan lain sebagainya. Dalam kontek pendidikan agama, satuan pendidikan keagamaan seperti madrasah pun memperlihatkan kecendrungan yang sama. Karenanya perluasan dan peningkatan akses pendidikan agama pun perlu diamati sebagai salah satu komponen pendidikan nasional.

Di Kabupaten Sorong Provinsi Papua Barat, ada kecenderungan peningkatan jumlah siswa baru dari tahun ke tahun. Peningkatan itu mendapat dampak dari program nasional dalam meningkatkan kualitas dan kuantitas sarana pendidikan. Pada tingkat satuan pendidikan dasar, dari sejumlah 11 MI pada tahun 2005, terdapat sejumlah 547 siswa. MIN Malewale yang memiliki jumlah siswa menampung siswa yang terbanyak yaitu sejumlah 221 siswa, kemudian MIS Al Baraqah (102 siswa) dan MIS Muhammadiyah I (98 siswa).

Pada tahun berikutnya, 2006, tampak peningkatan jumlah siswa MI di Kota Sorong. Peningkatan jumlah siswa itu mencapai 5\% dari jumlah siswa tahun sebelumnya, tahun 2005. Jumlah siswa MI di Kabupaten Sorong tahun 2006 mencapai 573 siswa. Sama dengan tahun sebelumnya, madrasah yang memiliki siswa terbanyak adalah MIN Malewale, MIS Al Baraqah, MIS Muhammadiyah I dan MIS Muhammadiyah II. Pada tahun 2007 peningkatan daya tampung MI pun meningkat $12 \%$ dari tahun sebelumnya. Jumlah siswa madrasah ibtidaiyah tahun 2007 sebanyak 642 orang. Demikian halnya pada tahun 2008 dan 2009, peningkatan daya tampung MI pun tampak, yaitu $12 \%$ dan $48 \%$ dari tahun sebelumnya.

Pada tingkat MTs, perkembangan daya tampung madrasah di 9 MTs lima tahun terakhir tampak cenderung konstan. Pada tahun 2006 perkembangan daya tampung MTs di Kabupaten Sorong meningkat sebesar $6 \%$ dari tahun sebelumnya. Tampak pada bahwa pada tahun 2005 jumlah daya tampung madrasah sebanyak 255 orang meningkat pada tahun 2006 menjadi sejumlah 271 siswa. Pada tahun 2007 perkembangan daya tampung MTs pun meningkat mencapai 30\% dari tahun sebelumnya, dengan jumlah siswa sebanyak 352 siswa. Hal serupa pada tahun 2007 dan 2008, perkembangan daya tampung MTs cenderung terus meningkat. Pada tahun 2007 peningkatan daya tampung MTs meningkat mencapai $27 \%$ dari tahun sebelumnya dan pada tahun 2008 mencapai $28 \%$ dari tahun sebelumnya.

Pada tingkat MA pun tampak perkembangan daya tampung madrasah cenderung meningkat. Dari sejumlah 5 MA di Kabupaten Sorong peningkatan jumlah daya tampung madrasah tampak meningkat setiap tahun. Pada tahun 2006 peningkatan jumlah daya tampung MA meningkat sangat tinggi, yaitu mencapai $102 \%$ dari tahun sebelumnya, dimana jumlah siswa MA pada tahun 2005 sebanyak 52 siswa meningkat pada tahun 2006 
menjadi 105 siswa. Pada tahun 2007 pun jumlah daya tampung MA meningkat sebanyak $23 \%$ dari tahun sebelumnya, 129 siswa. Demikian halnya pada dua tahun terakhir, yaitu tahun 2008 dan
2009. Pada tahun 2008 peningkatan daya tampung MA mencapai 58\% dan pada tahun 2009 mencapai $23 \%$. Untuk lebih jelasnya dapat dilihat pada tabel 3 berikut :

Tabel 3

Perkembangan Daya Tampung Madrasah di Kabupaten Sorong

\begin{tabular}{ccccccc}
\hline \multicolumn{2}{c}{ Siswa Madrasah } & 2005 & 2006 & 2007 & 2008 & 2009 \\
\hline \multirow{2}{*}{$11 \mathrm{MI}$} & Jumlah & 547 & 573 & 642 & 717 & 1.062 \\
& Perkembangan & & $5 \%$ & $12 \%$ & $12 \%$ & $48 \%$ \\
\multirow{2}{*}{$9 \mathrm{MTs}$} & Jumlah & 255 & 271 & 352 & 448 & 575 \\
& Perkembangan & & $6 \%$ & $30 \%$ & $27 \%$ & $28 \%$ \\
\multirow{2}{*}{$5 \mathrm{MA}$} & Jumlah & 52 & 105 & 129 & 204 & 251 \\
& Perkembangan & & $102 \%$ & $23 \%$ & $58 \%$ & $23 \%$ \\
\hline \multicolumn{2}{l}{ Catatan: Dianalisis berdasarkan data yang diperoleh dari Kantor Departemen Agama RI Kab. Sorong. }
\end{tabular}

\section{Peningkatan Jumlah Lulusan Madrasah}

Peningkatan jumlah lulus MI di Kabupaten Sorong tampak mengalami fluktuasi. Para tahun 2006, peningkatan jumlah lulus tampak dari kesebelas MI, yaitu 15\% dari jumlah lulusan tahun 2005. Pada tahun 2007 jumlah lulusan MI tampak mengalami penurunan mencapai $22 \%$. Sedangkan pada tahun 2008 peningkatannya tampak signfikan, yaitu mencapai $185 \%$ dari tahun sebelumnya, dan tahun 2009 penurunan jumlah lulusan pun terjadi yaitu mencapai $46 \%$ dari tahun sebelumnya.

Hal serupa pada perkembangan jumlah lulus MTs tampak memperlihatkan perkembangan, meskipun pada tahun 2007 jumlah lulus menurun dari tahun 2006. Pada tahun 2006 peningkatan jumlah lulusan MTs di Kabupaten Sorong mencapai 57\% dari jumlah lulusan tahun sebelumnya, 2005. Kemudian menurun pada tahun 2007 pada capaian $-10 \%$. Namun pada tahun 2008 dan 2009 jumlah lulusan meningkat, yaitu sejumlah $36 \%$ dari sebelumnya, dan pada tahun 2009 mencapai $41 \%$ dari tahun sebelumnya.

Demikian halnya dengan perkembangan jumlah lulusan MA, tampak mengalami peningkatan. Meskipun pada tahun 2006 jumlah lulusan MA di Kabupaten Sorong mengalami penurunan mencapai 52\%, namun pada tahun 2007 meningkat signifikan, yaitu mencapati $217 \%$ dari tahun sebelumnya. Kemudian dua tahun berikutnya tampak terjadi peningkatan, yaitu $74 \%$ pada tahun 2008 dan $45 \%$ pada tahun 2009. Untuk lebih jelasnya dapat dilihat pada tabel 4 .
Tabel 4

Perkembangan Jumlah Lulusan Madrasah Aliyah

\begin{tabular}{ccccc}
\hline \multirow{2}{*}{ Madrasah } & \multicolumn{4}{c}{ Tahun } \\
\cline { 2 - 5 } & 2006 & 2007 & 2008 & 2009 \\
\hline MI & $15 \%$ & $22 \%$ & $185 \%$ & $46 \%$ \\
MTs & $57 \%$ & $-10 \%$ & $36 \%$ & $-41 \%$ \\
MA & $-54 \%$ & $217 \%$ & $74 \%$ & $45 \%$ \\
\hline Sumber: Kemenag Kab.sorong, 2012
\end{tabular}

\section{Peningkatan Jumlah Lulusan MA yang Terjaring di Perguruan Tinggi}

Perkembangan jumlah lulusan MA, yang terjaring di Perguruan Tinggi, baik negeri maupun swasta pun tampak meningkat di Kabupaten Sorong, meskipun nominalnya masih minim. Pada tahun 2006 jumlah lulusan MA yang terjaring di PTN/PTAN tampak menurun, yaitu mencapai 33\%. Sedangkan pada tahun 2007 tampak tidak ada peningkatan keterjaringan di PTN/PTAN, jumlah siswa yang terjaring pada tahun itu sama dengan jumlah siswa pada tahun 2006. Namun pada tahun 2008 peningkatan jumlah lulusan MA yang terjaring di PTN/PTAN meningkat cukup signifikan, yaitu mencapai $250 \%$ dari tahun sebelumnya. Sedangkan pada tahun 2009 peningkatannya mencapai 14\% dari tahun sebelumnya.

Sedangkan peningkatan keterjaringan lulusan MA pada PTS/PTAS tampak fluktuatif. Pada tahun 2006 jumlah lulusan MA di Kabupaten Sorong yang terjaring di PTS/PTAS tampak menurun, yaitu mencapai $50 \%$. Namun pada tahun berikutnya 2007, peningkatan jumlah lulusan yang berhasil memasuki PTS/PTAS meningkat sampai 300\%. Demikian halnya dengan tahun 2008, peningkatan 
jumlah lulusan yang masuk PTS/PTAS meningkat sejumlah $75 \%$. Namun tahun 2009 , jumlah yang terjaring mencapai $7 \%$ dari tahun sebelumnya. Untuk lebih jelasnya dapat dilihat tabel 5 .

\section{Tabel 5}

Perkembangan Jumlah Lulusan MA yang Terjaring di Perguruan Tinggi

\begin{tabular}{lcccc}
\hline Perguruan & \multicolumn{4}{c}{ Tahun } \\
\cline { 2 - 5 } Tinggi & 2006 & 2007 & 2008 & 2009 \\
\hline PTN/PTAN & $-33 \%$ & $0 \%$ & $250 \%$ & $14 \%$ \\
PTS/PTAS & $10 \%$ & $300 \%$ & $75 \%$ & $-7 \%$ \\
\hline Catatan: Dianalisis berdasarkan data & yang diperoleh dari \\
Kantor Departemen Agama RI Kab. Sorong.
\end{tabular}

\section{PENUTUP}

Satuan pendidikan agama dan keagamaan Islam di Kabupaten Sorong telah tersentuh implementasi kebijakan perluasan dan pemerataan akses pendidikan agama berupa (a) rehabiliatasi gedung merehabilitasi fisik gedung sekolah/ruang kelas, rumah dinas penjaga/guru/kepala sekola, (b) mengadakan/ merehabilitasi sarana sanitasi air bersih dan sarana mandi, cuci, kakus (MCK), (c) pengadakan meubelair, (d) mengadakan sarana perpustakaan beserta perlengkapannya. Namun tingkat ketersentuhan itu tampak belum menyeluruh. Demikian halnya pada kebijakan peningkatan kesejahteraan guru dan bantuan beasiswa bagi siswa pun tampak. Peningkatan daya tampung satuan pendidikan agama di Kabupatern Sorong pun tampak. Hal ini dapat dilihat pada peningkatan jumlah siswa, tamatan pada setiap tingkatan pendidikan serta jumlah siswa yang terjaring di PTN/PTAN dan PTS/PTAS.

\section{UCAPAN TERIMA KASIH}

Ucapan terima kasih penulis haturkan kepada Kepada Kepala Balai Litbang Agama Makassar yang telah menugaskan penulis melakukan penelitian ini, kepada rekan peneliti bidang pendidikan, Kantor Kementerian Agama dan Kasi Mapenda Kabupaten Sorong, redaktur AlQalam dan semua pihak yang telah memberikan kontribusi dalam tulisan ini.

\section{DAFTAR PUSTAKA}

Departemen Pembangunan Daerah Tertinggal, 2005, Keputusan Menteri Negara Pembangunan
Daerah Tertinggal Nomor: 001/Kep/MPdt/I/2005 Tanggal 27 Januari 2005 Tentang Strategi Nasional Pembangunan Daerah Tertinggal.

Departemen Pendidikan Nasional, 2003, UndangUndang RI No. 20 Tahun 2003 Tentang Sistem Pendidikan Nasional (Sisdiknas), Bandung: Fokus Media,

Departemen Pendidikan Nasional, 2007, Menteri Pendidikan Nasional Republik Indonesia Nomor 4 Tahun 2007 Tentang Petunjuk Teknis Pelaksanaan Dana Alokasi Khusus (DAK) Bidang Pendidikan Tahun Anggaran 2007.

Direktorat Jendral Pendidikan Islam Departemen Agama Republik Indonesia, 2004, Renstra Dirjen Pendididikan Agama 2004-2009, Jakarta: Direktorat Jendral Pendidikan Islam Departemen Agama Republik Indonesia.

Direktorat Pendidikan Agama Islam, Departemen Agama RI, 2008, Laporan Evaluasi Tahun 2007, Jakarta: Direktorat Penddidikan Agama Islam.

Dirjen Kelembagaan Agama Islam, 2004, Direktorat Pendidikan Keagamaan dan Pondok Pesantren, Departemen Agama RI, 2004, Petunjuk Teknis Pondok Pesantren.

Dirjen Pendidikan Agama Islam Departemen Agama RI, 2008, Renstra Dirjen Pendidikan Agama 2004-2009, Kebijakan Umum bidang Madrasah dan pendidikan Agama Islam.

Eka, R. 2007. Kondisi Pemerataan Pendidikan di Indonesia, (http://edu-articles.com, diakses 9 Maret 2009)

Kurniati, Anna, 2012, Kajian SDM Kesehatan di Indonesia, Jakarta: Penerbit Salemba Media.

Prijono, Onny S, A.M.W. Pranarka, 1996, Pemberdayaan: Konsep, Kebijakan, dan Implementasi, Jakarta: Centre for Strategic and International Studies.

Saud, Udin Syaefuddin Saud, Mulyani Sumantri, 2007, "Pendidikan Darsa dan Menengah", dalam Tim Pengembang Ilmu Pendidikan Fakultas Ilmu Pendidikan Universitas Penndidikan Indonesia, Ilmu dan Aplikasi Pendidikan, Jakarta: PT. Imperial Bakti.

T. Sulistyono, Drs. M.Pd.,MM. 2003. Wawasan Pendidikan. Direktorat Pendidikan Lanjutan Pertama, Direktorat Jenderal Pendidikan Dasar dan Menengah, Departemen Pendidikan Nasional. 
Tim Pengembang Ilmu Pendidikan Fakultas Ilmu Pendidikan Universitas Pendidikan Indonesia, tt, Ilmu dan Aplikasi Pendidikan, Jakarta: PT. Imperial Bakti Utama.

Tirtarahardja, Umar dan S.L. La Sulo. 2005. Pengantar Pendidikan. Jakarta: Rineka Cipta
Winarno, Budi, 2008, Globalisasi: Peluang atau Tantangan Bagi Indonesia, Jakarta: Erlangga.

Wrihatnolo, Randy R, Rian Nogroho Dwidjowijoto, 2007, Manajemen Pemberdayaan, Sebuah Pengantar dan Pedoman untuk Pemberdayaan Masyarakat, Jakarta: PT. Elex Media Komputindo. 